\title{
PENGARUH KOMPOS CAMPURAN AMPAS DAUN SEREH WANGI DENGAN ABU TERBANG TERHADAP PERTUMBUHAN Cananga odorata
}

\author{
Effect of Citronella Leaf Waste - Fly Ash Compost on \\ the Growth of Cananga odorata
}

\author{
ALFI L. ZUHRIANSAH ${ }^{1}$, IRDIKA MANSUR ${ }^{2 *}$ dan SRI W. BUDI R. ${ }^{2}$ \\ ${ }^{1}$ Program Studi Silvikultur Tropika, Sekolah Pascasarjana, Institut Pertanian Bogor \\ ${ }^{2}$ Departemen Silvikultur, Fakultas Kehutanan, Institut Pertanian Bogor \\ Jalan Lingkar Kampus, Dramaga, Bogor 16680 \\ Telp.: +62-251-8621947, Fax.: +62-251-8621947 \\ e-mail: alzuh18@gmail.com \\ *Korespondensi, e-mail: irdikam@gmail.com
}

\begin{abstract}
ABSTRAK
Abu terbang digunakan sebagai bahan campuran alternatif dalam pengomposan ampas daun sereh wangi sebagai pengganti dolomit. Campuran ampas daun sereh wangi dengan 2\%, 5\%, 10\%, dan 15\% abu terbang, ditambah $2 \%$ dolomit maupun tanpa penambahan bahan alkali dikomposkan terlebih dahulu. Kompos ditambahkan ke dalam tanah dengan perbandingan 1:1 b/b untuk mengetahui pengaruhnya terhadap pertumbuhan Cananga odorata. Parameter pertumbuhan yang diamati yaitu pertambahan tinggi dan diameter tanaman, jumlah akar sekunder, panjang akar, berat kering pucuk dan akar, biomassa total, serapan hara, serta nisbah pucuk akar yang dianalisis 6 minggu setelah tanam. Analisis kandungan C-organik, N, P, K, Cu, Mn, Cd, $\mathrm{Pb}$, dan As dilakukan pada media dan jaringan tanaman yang mendapat perlakuan tanah dengan penambahan kompos dari campuran ampas daun sereh wangi dengan 15\% abu terbang (P6) dan dibandingkan dengan kandungan nutrisi yang sama pada media tanah tanpa kompos $(\mathrm{K})$ maupun media dengan kompos dari campuran ampas daun sereh wangi dengan $2 \%$ dolomit (P2). Perlakuan P6 menghasilkan N, P dan K total yang cenderung tinggi, meningkatkan akumulasi dan serapan $\mathrm{N}$ hingga $20 \%$, serta $\mathrm{pH}$ media tanam yang stabil pada kondisi netral. Perlakuan P6 juga menghasilkan konsentrasi $\mathrm{Pb}, \mathrm{Mn}, \mathrm{Cu}$, As dan $\mathrm{Cd}$ dalam media tanam, serta akumulasinya dalam jaringan C. odorata yang rendah. Perlakuan P6 ke dalam tanah dapat menurunkan akumulasi Mn dan $\mathrm{Cu}$ dalam jaringan C. odorata. Berdasarkan hasil tersebut, kompos dengan campuran abu terbang dapat dimanfaatkan sebagai bahan alternatif pengganti kompos dengan campuran dolomit.
\end{abstract}

Kata kunci: ampas daun sereh wangi, Cananga odorata, abu terbang, serapan hara.

\begin{abstract}
Fly ash is used as an alternative additive material in composting the citronella leaves waste to replace the roles of dolomite. At first, the citronella leaves waste mixed with $2 \%, 5 \% 10 \%$, and $15 \%$ fly ash and added $2 \%$ dolomite or without any additive alkaline material were composted. The compost added to the soil medium with 1:1 w/w ratio to study its effect on the growth of Cananga odorata in the nursery. The growth parameters such as plant height and diameter, total of secondary roots, root length, shoot and root dry weight, total biomass, nutrient uptake and shoot to root ratio were analyzed. C-organic, $N, P, K, C u, M n C d, P b$, and $A s$ in the soil media and plant tissue of $C$. odorata were analyzed for every treatments: soil media with citronella leaves waste compost $+15 \%$ fly ash (P6), with citronella leaves waste compost $+2 \%$ dolomite (P2) and soil media without citronella leaves waste compost $(K)$. The results showed that P6 treatment produced higher total $N$,
\end{abstract}


$P$ and $K$ in the soil, increased the $N$ uptake and accumulation in plant tissue up to $20 \%$, and maintained soil $\mathrm{pH}$ in neutral conditions. Furthermore, the P6 treatment decreased the concentration of $\mathrm{Pb}, \mathrm{Mn}, \mathrm{Cu}, \mathrm{As}$ and $\mathrm{Cd}$ in the growth media, and also reduced the accumulation of $\mathrm{Mn}$ and $\mathrm{Cu}$ in $\mathrm{C}$. odorata tissues. Based on these results, compost mixed with fly ash could be used as alternative to replace compost mixed with dolomite.

Keywords: citronella leaves waste, Cananga odorata, fly ash, nutrient uptake.

\section{PENDAHULUAN}

Abu terbang atau fly ash merupakan limbah hasil pembakaran batubara yang berasal dari Pembangkit Listrik Tenaga Uap (PLTU) dan pabrik smelter di pertambangan mineral. Hingga saat ini, penimbunan abu terbang masih menjadi isu yang penting pada setiap industri penghasil. Pada 2016, Pulau Jawa menghasilkan abu terbang sebanyak 4,6 juta ton/bulan berasal dari PLTU Perusahaan Listrik Negara (PLN) dan Independent Power Producer (IPP) (Anggriawan, 2016). Berdasarkan Peraturan Pemerintah No. 101 Tahun 2014 (Pemerintah Republik Indonesia, 2014), Abu terbang dikategorikan ke dalam limbah bahan berbahaya dan beracun (B3). Kategori limbah B3 tersebut diberikan karena adanya kandungan logam berat dalam abu terbang yang dapat berbahaya untuk kesehatan lingkungan dan manusia, seperti $\mathrm{Pb}, \mathrm{Mn}, \mathrm{Cu}$, As dan Cd (KLH-Dalhousie University, 1992; Pemerintah Republik Indonesia, 2014; Singh, Kumar dan Ratha, 2016; Verma, Madan dan Hussain, 2016; Damayanti, 2018). Oleh sebab itu, Peraturan Pemerintah No. 101 Tahun 2014 (Pemerintah Republik Indonesia, 2014) mewajibkan pengelolaan abu terbang bagi setiap industri penghasil limbah tersebut.

Pengelolaan abu terbang yang sudah diizinkan di Indonesia adalah pemusnahan logam berat abu terbang dan pemanfaatan dalam bidang infrastruktur. Pemusnahan logam berat abu terbang membutuhkan biaya yang mahal, sehingga industri penghasil abu terbang memilih alternatif pemanfaatan dalam bidang infrastruktur (Murdifi, 2017). Pemanfaatan di bidang infrastruktur tersebut hanya dapat menyerap $\pm 49 \%$ total abu terbang yang ada dan masih berpusat di daerah Jawa (Anggriawan, 2016; Murdifi, 2017; Wibowo, Riani dan Kurniawan, 2018). Hal tersebut menyebabkan belum seimbangnya antara pemanfaatan dengan penimbunan abu terbang. Perencanaan pembangunan 35 Giga Watt pembangkit listrik tambahan (Yunita, 2018) akan menambah pemakaian bahan bakar batubara yang berpotensi menambah jumlah timbunan abu terbang di masa depan. Oleh sebab itu, perlu adanya alternatif lain untuk pemanfaatan abu terbang seperti pemanfaatan untuk bahan campuran dalam pengomposan agar lebih banyak abu terbang yang terserap untuk dikelola.

Karakteristik abu terbang di setiap industri penghasil berbeda-beda, ada yang bersifat alkali dan ada yang bersifat asam. Abu terbang yang bersifat alkali umumnya memiliki kandungan kalsium (Ca) sebesar 3-10\% (Damayanti, Untung dan Sahminan, 2004; Bhattacharya dan Kim, 2016; Andarini, Haryati dan Lutfia, 2018; Utami, 2018). Bahan dengan kandungan $\mathrm{Ca}$, seperti juga halnya dolomit $\left(\mathrm{MgCa}\left(\mathrm{CO}_{3}\right)_{2}\right)$, dapat digunakan untuk menstabilkan $\quad \mathrm{pH}$ pengomposan (Moelyaningrum, Ellyke dan Pujiati, 2013). Karakteristik kandungan $\mathrm{Ca}$ tersebut diharapkan dapat dimanfaatkan dalam pengomposan, tanpa menyebabkan pencemaran logam berat yang ada dalam abu terbang ke lingkungan. Karakteristik abu terbang tersebut dapat dimanfaatkan terutama di lingkungan pabrik smelter pertambangan mineral, sebagai upaya penyediaan bahan pembenah tanah untuk kegiatan revegetasi lahan pascatambang. Bahan organik untuk pengomposan dapat menggunakan ampas daun sereh wangi. Ampas daun sereh wangi tersebut akan tersedia dari penyulingan minyak atsiri yang direncanakan akan dibangun di lingkungan pertambangan (Eti, 2018).

Upaya untuk menghasilkan kompos campuran ampas daun sereh wangi dengan abu terbang yang memenuhi standar mutu nasional memerlukan pengujian pengaruh kandungan unsur hara serta logam berat terhadap lingkungan dan tanaman. Beberapa penelitian aplikasi abu terbang untuk meningkatkan pertumbuhan tanaman pertanian (padi dan sayur) sudah dilakukan (Lee $d k k$., 2006; Singh, Sharma dan Agrawal, 2008; Arivazhagan $d k k$., 2011; Mahale dkk., 2012). Namun akumulasi logam berat seperti $\mathrm{Pb}$ dan $\mathrm{Cd}$ dalam tanaman 
pertanian dapat mencapai 1,6 dan 5,0 ppm yang melebihi batas aman $(\mathrm{Pb}=0,3 \mathrm{ppm}$ dan $\mathrm{Cd}=0,2 \mathrm{ppm})$ untuk beberapa tanaman (Gupta dkk., 2007; Singh, Sharma dan Agrawal, 2008) sehingga menjadi masalah saat dikonsumsi manusia. Diperlukan tanaman alternatif selain tanaman pertanian yang dapat mengakumulasi logam berat dengan tetap mempunyai nilai ekonomi.

Dilaporkan bahwa pertumbuhan beberapa tanaman penghasil minyak atsiri, seperti Anethum graveolens L., Mentha x piperita L. dan Ocimum basilicum L. tidak terhambat serta tidak ada perubahan komposisi minyak atsiri yang dapat menurunkan nilai pasarnya dengan adanya logam berat $\mathrm{Cd}, \mathrm{Pb}$ dan $\mathrm{Cu}$ yang tinggi pada media tanam, masing-masing hingga 10, 500 dan $150 \mathrm{mg} \mathrm{L}^{-1}$ (Zheljazkov, Craker dan Xing, 2006). Oleh sebab itu, aplikasi pemanfaatan abu terbang untuk tanaman penghasil minyak atsiri merupakan alternatif yang sesuai dari segi ekonomi maupun kesehatan lingkungan. Salah satu tanaman yang mempunyai potensi penghasil minyak atsiri di Indonesia adalah pohon Cananga odorata (Rusli, 2010). Bunga pohon ini dapat dipanen dan disuling untuk menghasilkan minyak kenanga mulai umur 2-4 tahun, sehingga berpotensi dapat memberikan nilai ekonomi tinggi pada lahan bekas tambang lebih awal. Berdasarkan penjelasan tersebut, penelitian ini bertujuan untuk menganalisis pengaruh kompos campuran ampas daun sereh wangi dengan abu terbang terhadap pertumbuhan C. odorata.

\section{METODE}

Bahan yang digunakan dalam penelitian ini adalah abu terbang $(\mathrm{pH} \mathrm{8,5)}$ yang diperoleh dari proses pembakaran batubara pada PLTU di smelter PT Trimegah Bangun Persada, Halmahera Utara; ampas penyulingan daun sereh wangi (Cymbopogon nardus (L.) Rendl.) yang diperoleh dari PT Pemalang Agro Wangi, Jonggol, Bogor; serta tanah $(\mathrm{pH} 6,5)$ yang diperoleh dari kebun SEAMEO BIOTROP, Bogor. Tanaman yang digunakan adalah bibit C. odorata berumur 8 bulan.

\section{Prosedur Penelitian}

\section{Pengomposan.}

Pengomposan ampas daun sereh wangi yang ditambahkan abu terbang dilakukan di SEAMEO BIOTROP, Bogor. Pengomposan ampas daun sereh wangi dilakukan selama 12 minggu. Kompos yang dibuat terdiri dari beberapa macam komposisi seperti yang disajikan pada Tabel 1.

2. Perlakuan.

Penelitian perlakuan penambahan macam kompos ampas daun sereh wangi ke media tanam C. odorata dilakukan selama 6 minggu dari Desember 2018-Januari 2019, bertempat di rumah kaca SEAMEO BIOTROP, Bogor. Penelitian dilakukan selama 6 minggu menggunakan rancangan acak lengkap (RAL) yang terdiri dari 7 perlakuan dengan 5 kali ulangan. Satu ulangan terdiri dari 2 unit tanaman. Total tanaman yang diamati sebanyak 70 tanaman yang ditanam dalam polybag ukuran 20×15 cm. Perlakuan yang diberikan disajikan pada Tabel 2. Pemeliharaan dilakukan dengan penyiraman setiap hari. Media tanam yang digunakan berupa tanah yang sudah disterilkan menggunakan autoclave.

3. Parameter yang diamati

Parameter yang diamati meliputi C-organik, $\mathrm{pH}$, dan rasio $\mathrm{C} / \mathrm{N}$ dalam kompos, serta kandungan $\mathrm{N}, \mathrm{P}, \mathrm{K}, \mathrm{Mg}$, $\mathrm{Fe}, \mathrm{Ca}, \mathrm{Cu}, \mathrm{Mn}, \mathrm{Cd}$, $\mathrm{Pb}$, dan As pada abu terbang, dolomit, kompos, media tanam dan jaringan $C$. odorata. Parameter respon pertumbuhan yang diamati adalah pertambahan diameter dan tinggi tanaman, panjang akar, jumlah akar sekunder, berat kering akar dan pucuk, biomassa total, serapan hara (N, P dan $\mathrm{K}$ ), serta nisbah pucuk akar. Diameter dan tinggi tanaman diukur mulai dari $1 \mathrm{~cm}$ di atas tanah dan dilakukan setiap 2 minggu sekali. Pengukuran panjang akar, jumlah akar sekunder, berat basah dan berat kering (pucuk dan akar), biomassa total, serapan hara, serta nisbah pucuk akar dilakukan pada akhir penelitian. Jaringan akar dan pucuk $C$. odorata dikeringkan menggunakan oven dengan suhu $70^{\circ} \mathrm{C}$ selama 2-3 hari. Biomassa total diperoleh melalui penjumlahan bobot berat kering pucuk dan akar. Serapan hara N, P dan K dihitung dengan rumus serapan hara tanaman = bobot total biomassa tanaman $\mathrm{x} \%$ hara tanaman (Ardakani dkk., 2011). 
Tabel 1. Komposisi pengomposan ampas daun sereh wangi

\begin{tabular}{cl}
\hline Perlakuan & \multicolumn{1}{c}{ Keterangan } \\
\hline K & Ampas daun sereh wangi tanpa penambahan bahan alkali \\
D & Campuran ampas daun sereh wangi dengan $2 \%$ dolomit $(\mathrm{b} / \mathrm{b})$ \\
FA1 & Campuran ampas daun sereh wangi dengan $2 \%$ abu terbang $(\mathrm{b} / \mathrm{b})$ \\
FA2 & Campuran ampas daun sereh wangi dengan $5 \%$ abu terbang $(\mathrm{b} / \mathrm{b})$ \\
FA3 & Campuran ampas daun sereh wangi dengan $10 \%$ abu terbang $(\mathrm{b} / \mathrm{b})$ \\
FA4 & Campuran ampas daun sereh wangi dengan $15 \%$ abu terbang $(\mathrm{b} / \mathrm{b})$ \\
\hline
\end{tabular}

Keterangan: bahan alkali $=$ abu terbang atau dolomit, dan $\mathrm{b} / \mathrm{b}=$ berat $/$ berat.

Tabel 2. Perlakuan macam media tanam C. odorata

\begin{tabular}{cl}
\hline Perlakuan & \multicolumn{1}{c}{ Keterangan } \\
\hline K & Media tanah tanpa tambahan kompos \\
P1 & Media tanah : kompos ampas daun sereh wangi tanpa penambahan bahan alkali $(1: 1 \mathrm{~b} / \mathrm{b})$ \\
P2 & Media tanah : kompos dari campuran ampas daun sereh wangi dengan $2 \%$ dolomit $(1: 1 \mathrm{~b} / \mathrm{b})$ \\
P3 & Media tanah : kompos dari campuran ampas daun sereh wangi dengan $2 \%$ abu terbang $(1: 1 \mathrm{~b} / \mathrm{b})$ \\
P4 & Media tanah : kompos dari campuran ampas daun sereh wangi dengan $5 \%$ abu terbang $(1: 1 \mathrm{~b} / \mathrm{b})$ \\
P5 & Media tanah : kompos dari campuran ampas daun sereh wangi dengan $10 \%$ abu terbang $(1: 1 \mathrm{~b} / \mathrm{b})$ \\
P6 & Media tanah : kompos dari campuran ampas daun sereh wangi dengan $15 \%$ abu terbang $(1: 1 \mathrm{~b} / \mathrm{b})$ \\
\hline Keterangan: bahan alkali $=$ abu terbang atau dolomit, dan $\mathrm{b} / \mathrm{b}=$ berat/berat.
\end{tabular}

4. Analisis kandungan hara dan logam berat Analisis kandungan hara dan logam berat dilakukan di Laboratorium Tanah dan Tanaman, SEAMEO BIOTROP, Bogor. Analisis kandungan hara dan logam berat ini dilakukan pada abu terbang, dolomit, kompos, media pratanam dan pascapanen, serta jaringan akar dan pucuk tanaman $C$. odorata pascapanen. Kandungan hara yang dianalisis adalah C-organik, N, P, K, Ca, Mg, dan Fe. Logam berat yang dianalisis adalah $\mathrm{Mn}, \mathrm{Cu}, \mathrm{Cd}$, As dan $\mathrm{Pb}$ (Pemerintah Republik Indonesia, 2014). Analisis Corganik menggunakan metode Walkey \& Black, nitrogen $(\mathrm{N})$ menggunakan metode Kjeldahl, fosfor (P) total menggunakan metode $\mathrm{HNO}_{3}-\mathrm{HClO}_{4}$-Spektrofotometri, serta kalium $(\mathrm{K})$ total menggunakan metode $\mathrm{HNO}_{3}-\mathrm{HClO}_{4}$-Flame Emisi. Analisis kalsium $(\mathrm{Ca})$, magnesium $(\mathrm{Mg})$, besi $(\mathrm{Fe})$, tembaga $(\mathrm{Cu})$, mangan $(\mathrm{Mn})$, kadmium $(\mathrm{Cd})$, dan timbal $(\mathrm{Pb})$ total menggunakan metode $\left(\mathrm{HNO}_{3}-\mathrm{HClO}_{4}\right)-\mathrm{AAS}$, serta arsen (As) menggunakan metode $\left(\mathrm{HNO}_{3}-\mathrm{HClO}_{4}\right)-\mathrm{ICP}$ MS. Metode ekstraksi menggunakan $\mathrm{HNO}_{3}-$ $\mathrm{HClO}_{4}$ merujuk pada Eviati dan Sulaeman (2009). Analisis dilakukan pada perlakuan kontrol, P2 dan P6 dengan asumsi dapat mewakili semua perlakuan, karena tidak ada perbedaan nyata terhadap parameter pertumbuhan C. odorata.

\section{Analisis Data}

IBM SPSS Statistic 22 digunakan untuk menganalisis data respon pertumbuhan $C$. odorata yang terdiri dari tinggi, diameter, panjang akar, berat kering pucuk dan akar, biomassa total, serta nisbah pucuk akar dilakukan menggunakan analysis of variance (ANOVA) one way pada taraf nyata 5\%. Jika uji ANOVA pada taraf nyata $5 \%$ berpengaruh nyata, dilanjutkan dengan uji rentang berganda Duncan (Duncan's multiple range test/DMRT) pada taraf nyata $5 \%$ untuk menganalisis perlakuan yang memberi pengaruh berbeda secara signifikan.

\section{HASIL DAN PEMBAHASAN}

\section{Karakteristik Kimia Abu Terbang dan Dolomit}

Karakteristik kimia abu terbang dan dolomit dianalisis untuk mengetahui konsentrasi Fe, Ca dan $\mathrm{Mg}$, selain itu, juga untuk mengetahui konsentrasi logam $\mathrm{Cu}, \mathrm{Mn}, \mathrm{Cd}$, As dan $\mathrm{Pb}$. Hasil analisis kimia abu terbang dan dolomit disajikan pada Tabel 3.

Berdasarkan Tabel 3, konsentrasi $\mathrm{CaO}$ dan $\mathrm{MgO}$ dalam abu terbang lebih rendah dibandingkan dengan konsentrasinya pada dolomit. Konsentrasi $\mathrm{CaO}$ dan $\mathrm{MgO}$ dalam abu 
terbang masing-masing sebesar 2,56 dan $0,53 \%$, sementara itu konsentrasi $\mathrm{CaO}$ dan $\mathrm{MgO}$ total dalam dolomit masing-masing sebesar 12,43 dan 1,16\%. Konsentrasi $\mathrm{CuO}$ dan $\mathrm{PbO}$ dalam abu terbang mencapai 7,60 ppm. Konsentrasi $\mathrm{MnO}$ dalam abu terbang adalah 1263 ppm, konsentrasi $\mathrm{CdO}$ adalah 0,27 ppm. Konsentrasi $\mathrm{As}_{2} \mathrm{O}_{3}$ masih di bawah limit deteksi yaitu $<0,0001 \mathrm{ppm}$.

Tabel 3. Hasil analisis kimia abu terbang dan dolomit

\begin{tabular}{|c|c|c|c|}
\hline \multicolumn{2}{|c|}{ Parameter } & Abu Terbang & Dolomit \\
\hline $\mathrm{CaO}$ & $(\%)$ & 2,56 & 12,43 \\
\hline $\mathrm{MgO}$ & $(\%)$ & 0,53 & 1,16 \\
\hline $\mathrm{Fe}_{2} \mathrm{O}_{3}$ & $(\%)$ & 2,96 & \\
\hline $\mathrm{CuO}$ & (ppm) & 11,1 & - \\
\hline $\mathrm{MnO}$ & (ppm) & 1263 & - \\
\hline $\mathrm{CdO}$ & (ppm) & 0,27 & - \\
\hline $\mathrm{PbO}$ & (ppm) & 7,60 & - \\
\hline $\mathrm{As}_{2} \mathrm{O}_{3}$ & (ppm) & $<0,0001$ & - \\
\hline
\end{tabular}

\section{Karakteristik Kompos dengan Campuran Abu Terbang}

Karakteristik kompos ampas daun sereh wangi dengan beberapa perlakuan campuran bahan alkali disajikan pada Tabel 4. Kompos dari campuran ampas daun sereh wangi dengan 2$15 \%$ abu terbang (FA1-FA4) menghasilkan konsentrasi C-organik, rasio $\mathrm{C} / \mathrm{N}$, $\mathrm{pH}$, serta konsentrasi $\mathrm{Mn}$ dan Fe yang sudah memenuhi standar mutu (Kementerian Pertanian, 2011). Konsentrasi Ca, Mn dan Fe yang dihasilkan mengalami peningkatan seiring dengan peningkatan rasio abu terbang yang ditambahkan ke dalam pengomposan ampas daun sereh wangi, namun konsentrasi Mn dan Fe masih di bawah batas standar mutu Permentan (Kementerian Pertanian, 2011). Kompos dari campuran ampas daun sereh wangi dengan 2-15\% abu terbang (FA1-FA4) menghasilkan konsentrasi Mg sebesar 0,3\% yang sama dengan kompos tanpa bahan alkali (K).

Konsentrasi Ca dalam kompos mengalami peningkatan seiring meningkatnya rasio abu terbang yang ditambahkan dalam kompos ampas daun sereh wangi hingga sebesar $3 \%$. Konsentrasi Ca tersebut sama dengan konsentrasi Ca pada kompos dari campuran ampas daun sereh wangi dengan $2 \%$ dolomit (D). Wong $d k k$. (1997) dan Singh $d k k$. (2014) menyatakan bahwa terdapat abu terbang yang dapat menaikkan $\mathrm{pH}$ serta memiliki kapasitas sebagai buffer $\mathrm{pH}$, melalui adanya hidrolisis $\mathrm{Ca}$ dan Mg (Adriano dkk., 1980).

Tabel 4. Karakteristik kompos ampas daun sereh wangi

\begin{tabular}{|c|c|c|c|c|c|c|c|}
\hline \multirow{2}{*}{ Parameter } & \multicolumn{6}{|c|}{ Kompos } & \multirow{2}{*}{ Standar mutu* } \\
\hline & $\mathrm{K}$ & D & FA1 & FA2 & FA3 & FA4 & \\
\hline $\mathrm{pH}$ & 7,5 & 8 & 7,8 & 7,6 & 7,8 & 7,9 & $7-9$ \\
\hline C-Organik (\%) & 31,45 & 28,9 & 27,2 & 30,78 & 25,06 & 25,61 & $\min 15$ \\
\hline Rasio C/N & 14 & 14 & 13 & 14 & 12 & 13 & $15-25$ \\
\hline \multicolumn{8}{|l|}{ Hara makro } \\
\hline N Total (\%) & 2,22 & 2,03 & 2,10 & 2,14 & 2,04 & 1,93 & Total \\
\hline $\mathrm{P}_{2} \mathrm{O}_{5}(\%)$ & 0,42 & 0,3 & 0,13 & 0,13 & 0,14 & 0,13 & $\left(\mathrm{~N}+\mathrm{P}_{2} \mathrm{O}_{5}+\mathrm{K}_{2} \mathrm{O}\right)$ \\
\hline $\mathrm{K}_{2} \mathrm{O}(\%)$ & 2,13 & 1,82 & 0,2 & 0,2 & 0,2 & 0,21 & minimal $4 \%$ \\
\hline \multicolumn{8}{|l|}{ Hara mikro } \\
\hline Ca Total (\%) & 1,42 & 2,87 & 2,31 & 2,44 & 2,84 & 2,85 & - \\
\hline Mg Total (\%) & 0,31 & 0,97 & 0,29 & 0,3 & 0,33 & 0,34 & - \\
\hline Mn Total (ppm) & 917,8 & 809,9 & 445,4 & 442,6 & 365,6 & 360,6 & maks 5.000 \\
\hline Fe Total (ppm) & 4.949 & 4.942 & 4.705 & 4.757 & 5.413 & 5.385 & maks 9000 \\
\hline
\end{tabular}

Keterangan: $\quad \mathrm{K}=$ kompos ampas daun sereh wangi tanpa bahan alkali, $\mathrm{D}=$ kompos campuran ampas daun sereh wangi dengan $2 \%$ dolomit, FA1 = kompos campuran ampas daun sereh wangi dengan $2 \%$ abu terbang, FA2 = kompos campuran ampas daun sereh wangi dengan $5 \%$ abu terbang, FA3 = kompos campuran ampas daun sereh wangi dengan $10 \%$ abu terbang, FA4 = kompos campuran ampas daun sereh wangi dengan 15\% abu terbang

*Standar mutu mengacu pada Peraturan Menteri Pertanian No. 70 tahun 2011 tentang pupuk organik, pupuk hayati dan pembenah tanah (Kementerian Pertanian, 2011) 
Konsentrasi $\mathrm{N}$ yang dihasilkan kompos dari campuran ampas daun sereh wangi dengan 2$15 \%$ abu terbang (FA1-FA4) mencapai $2 \%$. Konsentrasi $\mathrm{N}$ tersebut tidak berbeda dengan kompos dari campuran ampas daun sereh wangi dengan $2 \%$ dolomit (D) maupun tanpa bahan alkali $(\mathrm{K})$, tetapi konsentrasi $\mathrm{P}$ dan $\mathrm{K}$ pada kompos dari campuran ampas daun sereh wangi dengan 2-15\% abu terbang (FA1-FA4) lebih rendah, masing-masing sebesar 0,1 dan $0,2 \%$.

Kompos dari campuran ampas daun sereh wangi dengan $2-15 \%$ abu terbang (FA1-FA4) menghasilkan konsentrasi P total 56,67\% lebih rendah dibandingkan kompos dari campuran ampas daun sereh wangi dengan dolomit (D). Hal tersebut mengindikasikan bahwa penambahan abu terbang lebih banyak menyebabkan kehilangan fosfor. Kehilangan hara $\mathrm{P}$ dengan adanya penambahan abu terbang pada pengomposan tersebut berbeda dengan yang dilaporkan oleh Fang $d k k$. (1999), Lau, Fang dan Wong (2001), Belyaeva dan Haynes (2009), dan Gabhane dkk. (2012) yaitu tidak mengalami kehilangan $P$ yang tinggi karena terjadi penurunan $\mathrm{P}$ terlarut disebabkan oleh adanya fiksasi $\mathrm{P}$ oleh $\mathrm{Ca}$ pada $\mathrm{pH}$ berkisar antara 7-12, serta terjadi penurunan Ca tertukar dengan adanya penambahan abu terbang.

Di sisi lain, jumlah fosfor terlarut dapat mencapai 5 hingga 10 kali lipat dilaporkan oleh Urvashi dkk. (2007) dan Hermawan dkk. (2013) sesaat setelah mencampurkan pupuk organik dengan abu terbang ( $\mathrm{pH} 8-9$ ) yang mengandung konsentrasi ikatan Ca-P yang rendah sebesar $\pm 290 \mathrm{mg} / \mathrm{kg}$. Aplikasi bahan organik dapat meningkatkan fosfor terlarut dalam abu terbang dengan mekanisme reaksi antara asam organik dengan P terikat (Kpomblekou-A dan Tabatabai, 2003). Mekanisme tersebut kemungkinan terjadi selama pengomposan sehingga menyebabkan penurunan $\mathrm{P}$ total dalam kompos dari campuran ampas daun sereh wangi dengan 2-15\% abu terbang (FA1-FA4). Manyapu, Mandpe dan Kumar (2018) yang menambahkan hingga $200 \mathrm{~g}$ abu terbang ke dalam pengomposan campuran sampah kering dan hijau, juga menghasilkan $\mathrm{pH}$ kompos sebesar 7 dan kandungan $\mathrm{P}$ total dalam kompos yang $62 \%$ lebih rendah dibandingkan dengan pengomposan tanpa abu terbang.

\section{Pengaruh Kompos dengan Campuran Abu Terbang terhadap Pertumbuhan Bibit $C$. odorata}

Persentase hidup bibit C. odorata mencapai $100 \%$ untuk semua perlakuan media tanam. Hasil analisis sidik ragam parameter pertumbuhan tinggi, diameter, jumlah akar sekunder, berat kering pucuk dan akar, panjang akar, nisbah pucuk akar, serta biomassa total bibit C. odorata disajikan pada Tabel 5. Hasil analisis sidik ragam menunjukkan bahwa penambahan macam kompos tidak berpengaruh nyata terhadap pertambahan diameter dan tinggi batang, jumlah akar sekunder dan biomassa total bibit C. odorata.

Table 5. Hasil analisis sidik ragam pengaruh perlakuan penambahan kompos ke dalam media tanam terhadap perameter pertumbuhan C. odorata

\begin{tabular}{lc}
\hline \multicolumn{1}{c}{ Parameter } & $\begin{array}{c}\text { Perlakuan pemberian } \\
\text { kompos }\end{array}$ \\
\hline Pertumbuhan diameter $(\mathrm{mm})$ & tn \\
Pertumbuhan tinggi $(\mathrm{cm})$ & tn \\
Biomassa total (g) & tn \\
Nisbah pucuk akar (NPA) & $*$ \\
Panjang akar (cm) & $*$ \\
Jumlah akar sekunder & tn \\
\hline Keterangan: & \\
tn = berpengaruh tidak nyata pada taraf $\alpha>5 \%$, \\
$*=$ berpengaruh nyata pada taraf $\alpha \leq 5 \%$.
\end{tabular}

Pertumbuhan tinggi bibit $C$. odorata berkisar antara 2,6-4,8 cm, pertumbuhan diameter berkisar antara 1-1,5 mm, jumlah akar sekunder berkisar antara 35-44, berat kering pucuk dan akar masing-masing berkisar antara 5-8 g dan 3$4 \mathrm{~g}$, serta biomassa total berkisar antara 4-6 g (Tabel 6). Noviardi (2013) juga melaporkan bahwa aplikasi abu terbang ke dalam tanah berpengaruh terhadap peningkatan biomassa Helianthus annus, namun menjadi tidak berpengaruh ketika abu terbang dikombinasikan dengan kompos. Biomassa tanaman berkorelasi dengan ketersediaan hara, dalam media tanam serta kemampuan tanaman dalam mengambil dan mengakumulasi unsur hara dari media tanam, seperti $\mathrm{P}$ dan $\mathrm{Mg}$ untuk menunjang pertumbuhannya (Facelli, Smith dan Smith, 2009; Setiyowati, Haryanti dan Hastuti, 2012; Zhu $d k k ., 2014)$. 
Table 6. Hasil analisis perlakuan penambahan kompos ke dalam media tanam terhadap parameter pertumbuhan C. odorata

\begin{tabular}{ccccccc}
\hline \multirow{2}{*}{ Perlakuan } & \multicolumn{7}{c}{ Parameter } \\
\cline { 2 - 6 } & $\begin{array}{c}\text { Pertumbuhan } \\
\text { Tinggi } \\
(\mathrm{cm})\end{array}$ & $\begin{array}{c}\text { Pertumbuhan } \\
\text { Diameter } \\
(\mathrm{cm})\end{array}$ & $\begin{array}{c}\text { Jumlah Akar } \\
\text { Sekunder }\end{array}$ & $\begin{array}{c}\text { Berat Kering } \\
\text { Pucuk }(\mathrm{g})\end{array}$ & $\begin{array}{c}\text { Berat Kering } \\
\text { Akar }(\mathrm{g})\end{array}$ & $\begin{array}{c}\text { Biomassa } \\
\text { Total }(\mathrm{g})\end{array}$ \\
\hline K & $4,83 \pm 2,46$ & $1,50 \pm 0,24$ & $36,70 \pm 3,79$ & $5,74 \pm 0,79$ & $4,26 \pm 0,79$ & $5,68 \pm 0,68$ \\
P1 & $2,61 \pm 0,92$ & $1,17 \pm 0,23$ & $37,50 \pm 2,16$ & $5,49 \pm 0,70$ & $4,23 \pm 0,70$ & $6,00 \pm 0,59$ \\
P2 & $3,33 \pm 1,23$ & $1,24 \pm 0,18$ & $34,90 \pm 2,26$ & $4,68 \pm 0,57$ & $3,73 \pm 0,57$ & $5,33 \pm 0,32$ \\
P3 & $3,29 \pm 0,97$ & $0,97 \pm 0,14$ & $37,60 \pm 2,03$ & $7,96 \pm 1,77$ & $4,03 \pm 1,77$ & $5,55 \pm 1,24$ \\
P4 & $3,09 \pm 2,62$ & $1,19 \pm 0,23$ & $36,30 \pm 2,00$ & $6,02 \pm 0,47$ & $3,64 \pm 0,47$ & $5,15 \pm 1,14$ \\
P5 & $2,81 \pm 1,27$ & $1,00 \pm 0,19$ & $44,30 \pm 3,63$ & $5,15 \pm 1,16$ & $3,09 \pm 1,16$ & $4,38 \pm 0,75$ \\
P6 & $2,88 \pm 1,51$ & $1,17 \pm 0,15$ & $37,40 \pm 2,00$ & $6,46 \pm 0,80$ & $4,18 \pm 0,80$ & $6,05 \pm 0,69$ \\
\hline
\end{tabular}

Keterangan: $\mathrm{K}=$ media tanah tanpa kompos, $\mathrm{P} 1=$ tanah:kompos ampas daun sereh wangi kontrol,

P2 = media tanah: kompos dari campuran ampas daun sereh wangi dengan $2 \%$ dolomit,

$\mathrm{P} 3=$ media tanah: kompos dari campuran ampas daun sereh wangi dengan $2 \%$ abu terbang,

$\mathrm{P} 4=$ media tanah: kompos dari campuran ampas daun sereh wangi dengan $5 \%$ abu terbang,

$\mathrm{P} 5=$ media tanah: kompos dari campuran ampas daun sereh wangi dengan $10 \%$ abu terbang,

P6 = media tanah: kompos dari campuran ampas daun sereh wangi dengan $15 \%$ abu terbang.

Hasil analisis DMRT terhadap parameter panjang akar dan nisbah pucuk akar bibit C. odorata disajikan pada Tabel 7. Parameter panjang akar bibit $C$. odorata menunjukkan tidak berbeda signifikan untuk media tanam dengan penambahan kompos campuran ampas daun sereh wangi dengan 2-15\% abu terbang (P3-P6) dengan media tanam tanpa kompos (K) maupun media tanam dengan penambahan kompos campuran ampas daun sereh wangi dengan $2 \%$ dolomit (P2). Tidak ada perbedaan signifikan terhadap panjang akar tanaman seperti dilaporkan oleh Gupta dan Sinha (2006), tetapi parameter lain seperti biomassa dan tinggi tanaman pada penambahan $10 \%$ abu terbang ke dalam media garden soil untuk tanaman Brassica junceadak disebabkan tersedianya hara makro dan mikro esensial untuk pertumbuhannya. Konsentrasi K, Na, Zn, Ca, Mg and Fe dalam abu terbang yang tinggi meningkatkan pertumbuhan tanaman (Kishor, Ghosh dan Kumar, 2010).

Perlakuan tanah dengan penambahan kompos dari campuran ampas daun sereh wangi dengan $15 \%$ abu terbang (P6) menghasilkan NPA sebesar 3, serta tidak menghasilkan perbedaan yang signifikan dengan perlakuan tanah yang ditambahkan kompos dari campuran ampas daun sereh wangi dengan $2 \%$ dolomit (P2). Nilai NPA pada perlakuan tanah dengan penambahan kompos dari campuran ampas daun sereh wangi dengan $2-10 \%$ abu terbang (P3-P5) berbeda secara signifikan dari perlakuan tanah dengan penambahan kompos dari campuran ampas daun sereh wangi dengan $2 \%$ dolomit, tetapi NPA yang dihasilkan masih dalam kategori optimum, yaitu 2-5 (Alrasyid, 1972). Nisbah pucuk akar dan panjang akar berkorelasi negatif dengan kekurangan hara dan konsentrasi logam berat yang tinggi (Sinha dan Gupta, 2005). Serapan hara N, P dan K juga merupakan faktor yang memengaruhi pertumbuhan tanaman (Tuheteru $d k k$., 2015; Arty, Budi dan Wasis, 2019). Meskipun terjadi kehilangan unsur hara $\mathrm{P}$ dan $\mathrm{K}$ yang lebih tinggi saat pengomposan (Tabel 4), tidak adanya perbedaan pertumbuhan $C$. odorata yang signifikan tersebut mengindikasikan bahwa penyerapan hara oleh tanaman $C$. odorata tidak terhambat dengan adanya penambahan kompos dari campuran ampas daun sereh wangi dengan 2-15\% abu terbang (P3-P6) ke dalam tanah.

\section{Kandungan Hara dan Logam Berat pada Media Tanam dengan Penambahan Kompos}

Kandungan hara dan logam berat pada media tanam bibit C. odorata disajikan pada Tabel 8 . Media tanah yang digunakan dalam penelitian ini memiliki konsentrasi $\mathrm{N}$ sedang, $\mathrm{P}$ sangat tinggi dan $\mathrm{K}$ tergolong tinggi (Eviati dan Sulaeman, 2009). Penambahan kompos dari campuran ampas daun sereh wangi dengan $15 \%$ abu terbang (P6) ke dalam tanah menghasilkan $\mathrm{pH} 7$ hingga akhir penelitian. Konsentrasi N, P dan $\mathrm{K}$ total dalam media pratanam dengan penambahan kompos dari campuran ampas daun sereh wangi dengan $15 \%$ abu terbang (P6), masing-masing sebesar 0,4\%, 2500 ppm dan >1000 ppm. Konsentrasi $\mathrm{N}$ tersebut sama dengan konsentrasi $\mathrm{N}$ perlakuan media pratanam 
dengan penambahan kompos dari campuran ampas daun sereh wangi dengan $2 \%$ dolomit (P2). Hal tersebut mengindikasikan bahwa ketika abu terbang dan pupuk organik ditambahkan ke dalam tanah, abu terbang tidak berkontribusi signifikan terhadap $\mathrm{N}$ total dalam tanah, melainkan pupuk organik yang berkontribusi terhadap $\mathrm{N}$ total dalam tanah (Ciecko, Zolnowski dan Chelstowski, 2010).

Perlakuan tanah dengan penambahan kompos dari campuran ampas daun sereh wangi dengan $15 \%$ abu terbang (P6) menghasilkan penurunan hara $\mathrm{P}$ total sebesar $3,37 \%$ pada media pascatanam. Jumlah penurunan $\mathrm{P}$ pada media pascatanam tersebut lebih rendah dibandingkan dengan perlakuan tanah dengan penambahan kompos dari campuran ampas daun sereh wangi dengan $2 \%$ dolomit (P2) yang sebesar $7,82 \%$. Stout, Sharpley dan Pionke (1998) dan Lee $d k k$. (2019) menemukan bahwa penambahan abu terbang ke dalam tanah dengan kadungan $P$ yang tinggi dapat mereduksi $\mathrm{P}$ terlarut dengan membentuk ikatan Ca-P, Al-P dan Fe-P. Mekanisme penurunan konsentrasi $P$ terlarut tersebut kemungkinan juga terjadi pada penelitian ini, sehingga penurunan konsentrasi hara $\mathrm{P}$ total yang terjadi dalam tanah lebih rendah dengan kehadiran abu terbang.

Table 7. Hasil uji DMRT pengaruh penambahan kompos ke dalam media tanam terhadap panjang akar dan nisbah pucuk akar (NPA) C. odorata

\begin{tabular}{ccl}
\hline Perlakuan & Panjang Akar $(\mathrm{cm})$ & \multicolumn{1}{c}{ NPA } \\
\hline K & $4,31 \pm 0,13 \mathrm{a}$ & $3,07 \pm 0,33 \mathrm{bc}$ \\
P1 & $4,04 \pm 0,15 \mathrm{ab}$ & $3,02 \pm 0,36 \mathrm{bc}$ \\
P2 & $3,65 \pm 0,16 \mathrm{~b}$ & $3,82 \pm 0,68 \mathrm{a}$ \\
P3 & $4,37 \pm 0,18 \mathrm{a}$ & $2,58 \pm 0,28 \mathrm{~cd}$ \\
P4 & $4,13 \pm 0,15 \mathrm{ab}$ & $2,09 \pm 0,27 \mathrm{~d}$ \\
P5 & $4,49 \pm 0,17 \mathrm{a}$ & $2,46 \pm 0,28 \mathrm{~cd}$ \\
P6 & $4,20 \pm 0,25 \mathrm{a}$ & $3,27 \pm 0,52 \mathrm{ab}$ \\
\hline
\end{tabular}

Keterangan: $\quad \mathrm{K}=$ media tanah tanpa kompos, $\mathrm{P} 1=$ tanah:kompos ampas daun sereh wangi kontrol,

$\mathrm{P} 2=$ media tanah: kompos dari campuran ampas daun sereh wangi dengan $2 \%$ dolomit,

P3 = media tanah: kompos dari campuran ampas daun sereh wangi dengan $2 \%$ abu terbang,

$\mathrm{P} 4=$ media tanah: kompos dari campuran ampas daun sereh wangi dengan $5 \%$ abu terbang,

P5 = media tanah: kompos dari campuran ampas daun sereh wangi dengan 10\% abu terbang

$\mathrm{P} 6=$ media tanah: kompos dari campuran ampas daun sereh wangi dengan $15 \%$ abu terbang.

* Angka-angka yang diikuti oleh huruf yang sama pada kolom yang sama menunjukkan tidak berbeda nyata berdasarkan uji DMRT pada taraf $\alpha \leq 5 \%$.

Table 8. Kandungan hara dan logam berat pada media tanam C. odorata

\begin{tabular}{|c|c|c|c|c|c|c|c|}
\hline \multirow{2}{*}{ Parameter } & \multicolumn{3}{|c|}{ Pratanam } & \multicolumn{3}{|c|}{ Pascapanen } & \multirow{2}{*}{$\begin{array}{c}\text { Standar } \\
\text { mutu }\end{array}$} \\
\hline & K & P2 & P6 & K & P2 & P6 & \\
\hline $\mathrm{pH}$ & 6,40 & 6,80 & 7,15 & 6,00 & 7,30 & 7,12 & \\
\hline N Total (\%) & 0,22 & 0,43 & 0,39 & 0,22 & 0,42 & 0,40 & \\
\hline $\mathrm{P}_{2} \mathrm{O}_{5}(\mathrm{ppm})$ & 2.223 & 2.954 & 2.584 & 2.249 & 2.723 & 2.497 & \\
\hline $\mathrm{K}_{2} \mathrm{O}(\mathrm{ppm})$ & 504 & 1969 & 1571 & 586 & 1517 & 1443 & \\
\hline \multicolumn{8}{|l|}{ Logam Berat } \\
\hline Cu Total (ppm) & 9,5 & 8,1 & 12 & 12 & 5,2 & 9,3 & $60-125^{\mathrm{a}}$ \\
\hline Mn Total (ppm) & 813 & 615 & 671 & 603 & 504 & 597 & $1.500^{\mathrm{a}}$ \\
\hline Cd Total (ppm) & $<\mathrm{mdl}$ & $<\mathrm{mdl}$ & $<\mathrm{mdl}$ & $<\mathrm{mdl}$ & $<\mathrm{mdl}$ & $<\mathrm{mdl}$ & $0,5^{\mathrm{a}}$ \\
\hline Pb Total (ppm) & $<\mathrm{mdl}$ & $<$ mdl & $<$ mdl & $<\mathrm{mdl}$ & $<$ mdl & $<\mathrm{mdl}$ & $100^{\mathrm{a}}$ \\
\hline As Total (ppm) & $<\mathrm{mdl}$ & $<$ mdl & $<$ mdl & $<$ mdl & $<\mathrm{mdl}$ & $<$ mdl & $0,1-40^{\mathrm{b}}$ \\
\hline
\end{tabular}

Keterangan: $\quad \mathrm{K}=$ media tanah tanpa kompos, $\mathrm{P} 2=$ media tanah: kompos dari campuran ampas daun sereh wangi dengan $2 \%$ dolomit dan $\mathrm{P} 6=$ media tanah: kompos dari campuran ampas daun sereh wangi dengan $15 \%$ abu terbang.

aKLH-Dalhousie University (1992)

bAlloway (1995)

${ }^{*} \mathrm{mdl}=$ limit deteksi pengukuran. 
Kemampuan kompos dengan campuran abu terbang yang menghasilkan $\mathrm{pH}$ tanah stabil pada kondisi netral dan menurunkan kehilangan $\mathrm{P}$ total tersebut dapat dimanfaatkan untuk mengurangi keterlindian $\mathrm{P}$ ke lingkungan saat kompos campuran abu terbang diaplikasikan ke dalam tanah untuk jangka waktu yang panjang. Aplikasi bahan organik dengan campuran abu terbang selama 12-24 bulan ke dalam tanah dapat menghasilkan $\mathrm{pH}$ tanah stabil dalam jangka panjang dibandingkan aplikasi bahan organik dengan kapur dolomit (Truter, 2008).

Logam $\mathrm{Cd}$, As dan $\mathrm{Pb}$ tidak terdeteksi ketika kompos campuran dari ampas daun sereh wangi dengan $15 \%$ abu terbang ditambahkan ke dalam tanah. Hal tersebut dapat terjadi karena ada pengenceran saat kompos dicampur dengan tanah. Konsentrasi $\mathrm{Cu}$ dan Mn lebih tinggi pada tanah dengan penambahan kompos dari campuran ampas daun sereh wangi dengan $15 \%$ abu terbang (P6). Namun, perlakuan media pascatanam dengan penambahan kompos dari campuran ampas daun sereh wangi dengan $15 \%$ abu terbang (P6) menghasilkan penurunan $\mathrm{Cu}$ dan Mn total yang lebih rendah, sebesar 22,5\% dan $11,02 \%$ dibandingkan perlakuan dengan penambahan kompos dari campuran ampas daun sereh wangi dengan $2 \%$ dolomit (P2) yang mengalami penurunan $\mathrm{Cu}$ dan $\mathrm{Mn}$ masing-masing sebesar 35,8 dan 18,04\%. Hal tersebut mengindikasikan bahwa kompos campuran ampas daun sereh wangi dengan abu terbang dapat mengurangi keterlarutan logam $\mathrm{Mn}$ dan $\mathrm{Cu}$ dalam media tanam $\mathrm{C}$. odorata. Penurunan $\mathrm{Cu}$ dan $\mathrm{Mn}$ terlarut juga dilaporkan pada penambahan hingga 25\% abu terbang ke dalam pengomposan bahan organik berupa sewage sludge (Wong $d k k ., 1997$ ) karena abu terbang yang bersifat basa menyebabkan keterlarutan logam berat lebih rendah (Wong, Li dan Wong, 1995).

\section{Akumulasi Hara dan Logam Berat pada Jaringan Bibit $C$. odorata dengan Penambahan Kompos}

Jumlah akumulasi hara N, P dan K, serta logam berat $\mathrm{Cd}, \mathrm{Pb}, \mathrm{As}, \mathrm{Mn}$, dan $\mathrm{Cu}$ dalam jaringan C. odorata disajikan pada Tabel 9. Tidak ada perbedaan jumlah akumulasi $\mathrm{N}$ dalam jaringan pucuk dan akar C. odorata pada media tanam dengan penambahan kompos dari campuran ampas daun sereh wangi dengan $15 \%$ abu terbang (P6) dan 2\% dolomit (P2). Namun, akumulasi $\mathrm{N}$ tersebut $20 \%$ lebih tinggi dari perlakuan media tanam tanpa kompos (K).

Perlakuan tanah dengan penambahan kompos dari campuran ampas daun sereh wangi dengan 15\% abu terbang (P6) menghasilkan akumulasi hara P dalam jaringan pucuk yang sama dengan perlakuan penambahan kompos dari campuran ampas daun sereh wangi dengan $2 \%$ dolomit (P2), tetapi akumulasinya dalam jaringan akar $20 \%$ lebih rendah dari perlakuan penambahan kompos dari campuran ampas daun sereh wangi dengan 2\% dolomit (P2). Penn dan Bryant (2006) mengaplikasikan abu terbang ke dalam tanah yang mengandung fosfor hingga 800 ppm, melaporkan bahwa abu terbang dapat mengurangi konsentrasi fosfor terlarut yang menyebabkan tidak dapat diserap oleh tanaman.

Table 9. Akumulasi hara dan logam berat pada jaringan bibit C. odorata

\begin{tabular}{|c|c|c|c|c|c|c|c|}
\hline \multirow{2}{*}{ Parameter } & \multicolumn{3}{|c|}{ Jaringan Pucuk } & \multicolumn{3}{|c|}{ Jaringan Akar } & \multirow{2}{*}{$\begin{array}{c}\text { Standar } \\
\text { mutu }\end{array}$} \\
\hline & K & P2 & P6 & K & P2 & P6 & \\
\hline \multicolumn{8}{|l|}{ Hara Makro } \\
\hline N Total $(\%)$ & 1,43 & 1,68 & 1,86 & 1,43 & 1,68 & 1,86 & \\
\hline $\mathrm{P}_{2} \mathrm{O}_{5}(\mathrm{ppm})$ & 4.704 & 5.246 & 5.381 & 1.896 & 8.471 & 6.768 & \\
\hline $\mathrm{K}_{2} \mathrm{O}(\mathrm{ppm})$ & 11.158 & 12.262 & 11.719 & 10.656 & 27.460 & 19.157 & \\
\hline \multicolumn{8}{|l|}{ Logam Berat } \\
\hline Cu Total (ppm) & 3,2 & 3,2 & 3,2 & 3,5 & 3,5 & 3,2 & $20-100^{a}$ \\
\hline Mn Total (ppm) & 25 & 16 & 19 & 145 & 107 & 36 & $20-1000^{c}$ \\
\hline Cd Total (ppm) & $<$ mdl & $<$ mdl & $<$ mdl & $<\mathrm{mdl}$ & $<$ mdl & $<$ mdl & $5-30^{\mathrm{a}}$ \\
\hline Pb Total (ppm) & $<\mathrm{mdl}$ & $<\mathrm{mdl}$ & $<\mathrm{mdl}$ & $<\mathrm{mdl}$ & $<$ mdl & $<$ mdl & $50^{\mathrm{a}}$ \\
\hline As Total (ppm) & $<\mathrm{mdl}$ & $<\mathrm{mdl}$ & $<\mathrm{mdl}$ & $<\mathrm{mdl}$ & $<\mathrm{mdl}$ & $<\mathrm{mdl}$ & $0,01-5^{b}$ \\
\hline \multicolumn{8}{|l|}{ Keterangan: $\quad \mathrm{K}=$} \\
\hline
\end{tabular}


Akumulasi $\mathrm{Cd}$, As dan $\mathrm{Pb}$ dalam jaringan $\mathrm{C}$. odorata tidak terdeteksi pada semua perlakuan. Tidak adanya akumulasi $\mathrm{Pb}$ yang terdeteksi dalam jaringan $C$. odorata pada perlakuan penambahan kompos dari campuran ampas daun sereh wangi dengan $15 \%$ abu terbang (P6) berbeda dengan yang dilaporkan oleh Hayati (2010) ketika tanaman tumbuh pada media abu terbang murni yang menunjukkan adanya akumulasi $\mathrm{Pb}$ dalam jaringan akar maupun pucuk sebesar $0,13 \mathrm{mg} \mathrm{g}^{-1}$.

Akumulasi $\mathrm{Cu}$ dan $\mathrm{Mn}$ total dalam jaringan tanaman pada semua perlakuan masih di bawah ambang batas (KLH-Dalhousie University, 1992; Alloway, 1995; Reeves dan Baker, 2000). Meskipun konsentrasi Cu dan $\mathrm{Mn}$ lebih tinggi pada media tanah dengan penambahan kompos dari campuran ampas daun sereh wangi dengan $15 \%$ abu terbang (P6) (Tabel 8), tetapi akumulasinya dalam jaringan $C$. odorata tidak lebih tinggi dari perlakuan lain. Penurunan $\mathrm{Cd}, \mathrm{Cu}, \mathrm{Mn}$, As dan $\mathrm{Pb}$ terlarut dilaporkan pada penambahan abu terbang hingga $25 \%$ ke dalam pengomposan sewage sludge (Wong $d k k ., 1997)$ disebabkan oleh sifat basa dari abu terbang (Wong, Li dan Wong, 1995).

Tidak ada kecenderungan perbedaan akumulasi $\mathrm{Cu}$ pada kedua jaringan untuk semua perlakuan. Hasil akumulasi $\mathrm{Cu}$ tersebut sejalan dengan yang dilaporkan oleh Gupta dan Sinha (2006) pada tanaman Brassica juncea yang ditumbuhkan pada media dengan penambahan abu terbang dengan $\mathrm{pH}$ berkisar antara 7-8.

Akumulasi Mn dalam jaringan akar C. odorata cenderung lebih tinggi dibandingkan jaringan pucuk pada semua perlakuan. Namun, akumulasi Mn dalam jaringan akar C. odorata cenderung lebih rendah ketika ditumbuhkan pada tanah dengan penambahan kompos dari campuran ampas daun sereh wangi dengan $15 \%$ abu terbang (P6) dibandingkan perlakuan lain. Akumulasi Mn dalam jaringan C. odorata pada perlakuan tanah dengan penambahan kompos dari campuran ampas daun sereh wangi dengan $15 \%$ abu terbang (P6) $75 \%$ lebih rendah dibandingkan tanah tanpa kompos (K) dan 78\% lebih rendah dibandingkan tanah dengan penambahan kompos dari campuran ampas daun sereh wangi dengan $2 \%$ dolomit (P2).
Akumulasi Mn dalam jaringan akar C. odorata lebih rendah pada perlakuan tanah dengan penambahan kompos dari campuran ampas daun sereh wangi dengan $15 \%$ abu terbang (P6). Hal tersebut dapat terjadi karena abu terbang mempunyai kapasitas adsorpsi logam $\mathrm{Mn}$ dengan adanya kandungan Silika (Si), sehingga dapat menurunkan konsentrasi $\mathrm{Mn}$ terlarut (Gobel, 2018).

Akumulasi Mn yang lebih tinggi dalam jaringan akar C. odorata dibandingkan jaringan lainnya, berbeda dengan yang dilaporkan Gupta dan Sinha (2006) bahwa akumulasi logam berat seperti Mn lebih tinggi di jaringan pucuk Brassica juncea. Hayati (2010) mengamati akumulasi logam berat pada Eupatorium odoratum, Passiflora foetida, Chlorisbarbata, Erigeron sumatrensis, Pithecellobium dulce yang tumbuh alami di landfill abu terbang, melaporkan bahwa kecenderungan akumulasi logam berat dalam jaringan pucuk dan akar berbeda pada setiap tanaman tersebut bergantung kepada kemampuannya sebagai akumulator, ekskluder atau indikator (Baker, 1981). Hal serupa tentang perbedaan kecenderungan akumulasi logam berat dalam jaringan beberapa tanaman juga dilaporkan oleh Tosepu (2012). Tanaman Chlorisbarbata dilaporkan mempunyai kemampuan sebagai ekskluder logam $\mathrm{Mn}, \mathrm{Cu}$ dan $\mathrm{Cd}$ karena tanaman ini dapat mengakumulasi logam tersebut lebih besar dalam jaringan akar ditunjukkan oleh nilai faktor translokasi (TF) $<1$ (Hayati, 2010). Akumulasi Mn yang lebih tinggi dalam jaringan akar C. odorata $(\mathrm{TF}<1)$ mengindikasikan tanaman tersebut juga mempunyai kemampuan sebagai ekskluder terhadap logam Mn untuk kegiatan fitoremediasi lahan pascatambang.

\section{Serapan Hara Tanaman C. odorata dengan Penambahan Kompos}

Berdasarkan analisis akumulasi hara dalam jaringan pucuk dan akar bibit $C$. odorata, maka dilakukan pula analisis serapan hara $\mathrm{N}, \mathrm{P}$ dan K yang disajikan pada Tabel 10. Bibit C. odorata yang ditumbuhkan pada media tanah dengan penambahan kompos dari campuran ampas daun sereh wangi dengan $15 \%$ abu terbang (P6) menghasilkan peningkatan serapan hara N, P dan K. Serapan hara P memiliki serapan paling kecil daripada hara $\mathrm{N}$ dan $\mathrm{K}$, pada semua media tanam. 
Table 10. Hasil analisis serapan hara N, P dan K pada bibit C. odorata

\begin{tabular}{cccccccc}
\hline Perlakuan & $\begin{array}{c}\text { Biomassa } \\
\text { Total }(\mathrm{g})\end{array}$ & $\% \mathrm{~N}$ & $\begin{array}{c}\text { Serapan } \mathrm{N} \\
\left(\mathrm{g} \mathrm{tan}^{-1}\right)\end{array}$ & $\% \mathrm{P}$ & $\begin{array}{c}\text { Serapan } \mathrm{P} \\
\left(\mathrm{g} \mathrm{tan}^{-1}\right)\end{array}$ & $\% \mathrm{~K}$ & $\begin{array}{c}\text { Serapan K } \\
\left(\mathrm{g} \mathrm{tan}^{-1}\right)\end{array}$ \\
\hline $\mathrm{K}$ & 5,68 & 2,86 & 16,24 & 0,66 & 3,75 & 2,17 & 12,32 \\
$\mathrm{P} 2$ & 5,33 & 3,36 & 17,91 & 1,37 & 7,30 & 3,97 & 21,16 \\
$\mathrm{P} 6$ & 6,05 & 3,72 & 22,51 & 1,22 & 7,38 & 3,08 & 18,63 \\
\hline
\end{tabular}

Keterangan: $\mathrm{K}=$ tanah tanpa kompos, $\mathrm{P} 2=$ tanah: kompos dari campuran ampas daun sereh wangi dengan $2 \%$ dolomit dan $\mathrm{P} 6=$ tanah: kompos dari campuran ampas daun sereh wangi dengan $15 \%$ abu terbang.

Bibit C. odorata yang ditumbuhkan pada media tanah dengan penambahan kompos dari campuran ampas daun sereh wangi dengan $15 \%$ abu terbang (P6) menghasilkan serapan hara $N$ sebesar 22,51 g/tanaman. Serapan tersebut $20 \%$ lebih tinggi daripada media tanah dengan penambahan kompos dari campuran ampas daun sereh wangi dengan $2 \%$ dolomit (P2) dan tanpa kompos (K). Serapan N tanaman yang tinggi dengan adanya penambahan campuran bahan organik dengan abu terbang ke dalam tanah juga dilaporkan oleh Rautaray, Ghosh dan Mittra (2003) pada tanaman padi dan kanola yang ditumbuhkan di tanah asam. Serapan $N$ yang tinggi dengan adanya penambahan kompos dari campuran ampas daun sereh wangi dengan $15 \%$ abu terbang (P6) disebabkan karena tidak terhambatnya mineralisasi $\mathrm{N}$ dalam tanah. Hal serupa dilaporkan oleh Topaç, Başkaya dan Alkan (2008) ketika menambahkan campuran sludge dengan $40-120 \%$ abu terbang yang menghasilkan jumlah mineralisasi yang sama dengan tanah yang ditambahkan sludge saja. Karakteristik abu terbang yang tidak menghambat mineralisasi $\mathrm{N}$ dalam tanah tersebut berbeda dengan karakteristik dolomit yang menurunkan mineralisasi $\mathrm{N}$ dalam tanah, yang menyebabkan rendahnya serapan $\mathrm{N}$ tanaman (Ibrahim dan Kasno, 2008).

Serapan $\mathrm{P}$ sebesar $7,38 \%$ dan $\mathrm{K}$ sebesar $18,63 \%$ pada media tanah dengan penambahan kompos dari campuran ampas daun sereh wangi dengan $15 \%$ abu terbang (P6). Serapan hara P dan K tersebut cenderung tidak berbeda dengan perlakuan media tanah dengan penambahan kompos dari campuran ampas daun sereh wangi dengan $2 \%$ dolomit (P2), namun serapannya lebih besar dibandingkan media tanam tanpa kompos (K).

Serapan N, P dan K yang tinggi pada C. odorata yang ditumbuhkan di media tanah dengan penambahan kompos dari campuran ampas daun sereh wangi dengan 15 abu terbang (P6) tidak menghasilkan adanya perbedaan yang signifikan terhadap parameter pertumbuhan bibit C. odorata dengan perlakuan lain. Hal serupa dengan yang terjadi terhadap pertumbuhan tanaman pada tanah yang ditambahkan abu terbang (Lee $d k k$., 2019). Rautaray, Ghosh dan Mittra (2003) melaporkan bahwa hara $\mathrm{P}$ dilepaskan secara lebih perlahan ketika kompos dengan abu terbang diaplikasikan ke dalam tanah. Hara $\mathrm{P}$ yang dilepaskan secara lebih perlahan tersebut dapat menjadi penyebab tidak adanya perbedaan pertumbuhan yang signifikan dengan kontrol karena ketersediaan hara $\mathrm{P}$ dapat menjadi faktor pembatas pertumbuhan (Bucher, 2007; Thuynsma $d k k ., 2016$; Lee $d k k ., 2019$ ).

\section{KESIMPULAN DAN SARAN}

Abu terbang dapat dimanfaatkan sebagai bahan alternatif pengganti dolomit dalam pengomposan ampas daun sereh wangi. Kompos dari campuran abu terbang tersebut juga tidak menghambat pertumbuhan $C$. odorata, serta tidak menghasilkan akumulasi logam berat yang tinggi dalam media tanam dan tanaman. Berdasarkan hasil tersebut, alternatif pemanfaatan abu terbang dalam pengomposan dan aplikasi kompos dari campuran abu terbang ke dalam tanah dapat mendukung progarm pemanfaatan limbah abu terbang.

\section{UCAPAN TERIMA KASIH}

Ucapan terima kasih ditujukan kepada SEAMEO BIOTROP, Bogor; PT Trimegah Bangun Persada, Halmahera Utara serta PT Pemalang Agro Wangi, Jonggol, yang telah menyediakan fasilitas tempat dan bahan untuk penelitian ini. 


\section{DAFTAR PUSTAKA}

Adriano, D. C., Page, A. L., Elseewi, A. A., Chang, A. C. dan Straughan, I. (1980) "Utilization and disposal of fly ash and other coal residues in terrestrial ecosystems: A review," Journal of Environmental Quality, 9(3), hal. 333-344. doi:

10.2134/jeq1980.00472425000900030001x.

Alloway, B. J. (ed.) (1995) Heavy metals in soils. 2 ed. Dordrecht: Springer Netherlands. doi: 10.1007/978-94-011-1344-1.

Alrasyid, H. (1972) Teknik persemaian dan penanaman di Jepang. Bogor: Forestry Reasearch Department of Bogor.

Andarini, N., Haryati, T. dan Lutfia, Z. (2018) "Sintesis zeolit A dari abu terbang (fly ash) batubara variasi rasio molar Si/AI," Jurnal ILMU DASAR, 19(2), hal. 105. doi: 10.19184/jid.v19i2.5910.

Anggriawan, V. (2016) Kebijakan pemerintah diharapkan dukung penyerapan fly ash bottom ash (FABA), www.jitunews.com. Tersedia pada:

https://www.jitunews.com/read/43485/kebija kan-pemerintah-diharapkan-dukungpenyerapan-fly-ash-bottom-ash-faba (Diakses: 8 Februari 2020).

Ardakani, M. R., Mazaheri, D., Mafakheri, S. dan Moghaddam, A. (2011) "Absorption efficiency of $N, P, K$ through triple inoculation of wheat (Triticum aestivum L.) by Azospirillum brasilense, Streptomyces sp., Glomus intraradices and manure application," Physiology and Molecular Biology of Plants, 17(2), hal. 181-192. doi: 10.1007/s12298011-0065-7.

Arivazhagan, K., Ravichandran, M., Dube, S. K. Mathur, V. K., Khandakar, R. K., Yagnanarayana, K., Pasha, K. M. M., Sinha, A. K., Sarangi, B. D., Tripathi, V. K. M., Gupta, S. K., Singh, R., Ali, M., Thakur, A. S. dan Narayan, R. (2011) "Effect of coal fly ash on agricultural crops: Showcase project on use Of fly ash in agriculture in and around thermal power station areas of National Thermal Power Corporation Ltd., India," in 4th World of Coal Ash (WOCA) Conference. Denver: World of Coal Ash (WOCA), hal. 016-1-016-046.

Arty, B., Budi, S. W. dan Wasis, B. (2019) Aplikasi tipe mycosilvi dan amelioran tanah pada dua jenis tanaman kehutanan di media tanah pascatambang pasir silika. Institut Pertanian Bogor.
Baker, A. J. M. (1981) "Accumulators and excludersstrategies in the response of plants to heavy metals," Journal of Plant Nutrition, 3(1-4), hal. 643-654. doi: 10.1080/01904168109362867.

Belyaeva, O. N. dan Haynes, R. J. (2009) "Chemical, microbial and physical properties of manufactured soils produced by co-composting municipal green waste with coal fly ash," Bioresource Technology, 100(21), hal. 52035209. doi: 10.1016/j.biortech.2009.05.032.

Bhattacharya, S. S. dan Kim, K.-H. (2016) "Utilization of coal ash: Is vermitechnology a sustainable avenue?," Renewable and Sustainable Energy Reviews, 58, hal. 13761386. doi: 10.1016/j.rser.2015.12.345.

Bucher, M. (2007) "Functional biology of plant phosphate uptake at root and mycorrhiza interfaces," New Phytologist, 173(1), hal. 1126. doi: 10.1111/j.1469-8137.2006.01935.x.

Ciecko, Z., Zolnowski, A. C. dan Chelstowski, A. (2010) "Long-term effect of coal fly ash application on soil total nitrogen and organic carbon concentrations," in Kulakow, P. A. dan Pidlisnyuk, V. V. (ed.) Application of Phytotechnologies for Cleanup of Industrial, Agricultural, and Wastewater Contamination. pringer Nature, hal. 147-158. doi: 10.1007/978-90-481-3592-9_10.

Damayanti, R. (2018) "Abu batubara dan pemanfaatannya: Tinjauan teknis karakteristik secara kimia dan toksikologinya," Jurnal Teknologi Mineral dan Batubara, 14(3), hal. 213-231. doi: 10.30556/jtmb.Vol14.No3.2018.966

Damayanti, R., Untung, S. R. dan Sahminan, S. (2004) "Pengujian abu terbang/fly ash (limbah B3 dalam PP No, 85/1999)," Jurnal Teknologi Mineral dan Batubara, 2(2), hal. 29-34.

Eti, R. A. (2018) "Prospek budidaya \& pemasaran sereh wangi," in Materi talkshow SEAMEO BIOTROP. Bogor.

Eviati dan Sulaeman (2009) Analisis kimia tanah, tanaman, air dan pupuk. Bogor: Balai Penelitian Tanah.

Facelli, E., Smith, S. E. dan Smith, F. A. (2009) "Mycorrhizal symbiosis - overview and new insights into roles of arbuscular mycorrhizas in agro- and natural ecosystems," Australasian Plant Pathology, 38(4), hal. 338. doi: 10.1071/AP09033.

Fang, M., Wong, J. W. C., Ma, K. K. dan Wong, M. H. (1999) "Co-composting of sewage sludge 
and coal fly ash: Nutrient transformations," Bioresource Technology, 67(1), hal. 19-24. doi: 10.1016/S0960-8524(99)00095-4.

Gabhane, J., William, S. P., Bidyadhar, R., Bhilawe, P., Anand, D., Vaidya, A. N. dan Wate, S. R. (2012) "Additives aided composting of green waste: Effects on organic matter degradation, compost maturity, and quality of the finished compost," Bioresource Technology, 114, hal. 382-388.

doi: 10.1016/j.biortech.2012.02.040.

Gobel, A. P. (2018) "Efektifitas pemanfaatan fly ash batubara sebagai adsorben dalam menetralisir air asam tambang pada settling pond penambangan banko PT. Bukit Asam (Persero), Tbk," Jurnal Mineral, Energi dan Lingkungan, 2(1), hal. 1-11. doi: 10.31315/jmel.v2i1.2113.

Gupta, A. K., Dwivedi, S., Sinha, S., Tripathi, R. D., Rai, U. N. dan Singh, S. N. (2007) "Metal accumulation and growth performance of Phaseolus vulgaris grown in fly ash amended soil," Bioresource Technology, 98(17), hal. 3404-3407.

doi: 10.1016/j.biortech.2006.08.016.

Gupta, A. dan Sinha, S. (2006) "Role of Brassica juncea (L.) Czern. (var. Vaibhav) in the phytoextraction of $\mathrm{Ni}$ from soil amended with fly ash: Selection of extractant for metal bioavailability," Journal of Hazardous Materials, 136(2), hal. 371-378. doi: 10.1016/j.jhazmat.2005.12.025.

Hayati, R. (2010) Karakterisasi abu terbang (fly ash) dan eksplorasi vegetasi fitoremediasi di area landfill abu terbang untuk pengelolaan ramah lingkungan. Institut Pertanian Bogor.

Hermawan, A., Kadir, S., Masri dan Hayati, R. (2013) "Status jerapan dan ketersediaan P abu terbang batubara akibat penambahan kotoran ayam," in Herlinda, S. et al. (ed.) Intensifikasi Pengelolaan Lahan Sub-optimal dalam Rangka Mendukung Kemandirian Pangan Nasional. Palembang: UniversitasSriwijaya, hal. 245-255.

Ibrahim, A. S. dan Kasno, A. (2008) “Interaksi pemberian kapur pada pemupukan urea terhadap kadar $\mathrm{N}$ tanah dan serapann tanaman jagung (Zea mays. L)," in Prosiding Seminar Nasional dan Dialog Sumberdaya Lahan Pertanian. Jakarta: Balai Besar Penelitian dan Pengembangan Pertanian, hal. 313-327.

Kementerian Pertanian (2011) Peraturan Menteri Pertanian Nomor 70 Tahun 2011 Tentang Pupuk Organik, Pupuk Hayati dan Pembenah Tanah. Indonesia.
Kishor, P., Ghosh, A. K. dan Kumar, D. (2010) "Use of flyash in agriculture: A way to improve soil fertility and its productivity," Asian Journal of Agricultural Research, 4(1), hal. 1-14. doi: 10.3923/ajar.2010.1.14.

KLH-Dalhousie University (1992) "Environmental managemental development in Indonesia," in Indonesia Environmental Soil Quality Criteria for Contaminated Site. Ministry States for Population and Environmental Republic of Indonesia and Dalhousie University Canada, hal. 5-8.

Kpomblekou-A, K. dan Tabatabai, M. A. (2003) "Effect of low-molecular weight organic acids on phosphorus release and phytoavailabilty of phosphorus in phosphate rocks added to soils," Agriculture, Ecosystems \& Environment, 100(2-3), hal. 275-284. doi: 10.1016/S01678809(03)00185-3.

Lau, S. S. S., Fang, M. dan Wong, J. W. C. (2001) "Effects of composting process and fly ash amendment on phytotoxicity of sewage sludge," Archives of Environmental Contamination and Toxicology, 40(2), hal. 184-191. doi: 10.1007/s002440010162.

Lee, D.-S., Lim, S.-S., Park, H.-J., Yang, H. I., Park, S.-I., Kwak, J.-H. dan Choi, W.-J. (2019) "Fly ash and zeolite decrease metal uptake but do not improve rice growth in paddy soils contaminated with $\mathrm{Cu}$ and $\mathrm{Zn}$," Environment International, 129, hal. 551-564. doi: 10.1016/j.envint.2019.04.032.

Lee, H., Ha, H. S., Lee, C. H., Lee, Y. B. dan Kim, P. J. (2006) "Fly ash effect on improving soil properties and rice productivity in Korean paddy soils," Bioresource Technology, 97(13), hal. 1490-1497.

doi: 10.1016/j.biortech.2005.06.020.

Mahale, N. K., Patil, S. D., Sarode, D. B. dan Attarde, S. B. (2012) "Effect of fly ash as an admixture in agriculture and the study of heavy metal accumulation in wheat (Triticum aestivum), mung bean (Vigna radiata), and urad beans (Vigna mungo)," Polish Journal of Environmental Studies, 21(6), hal. 1713-1719.

Manyapu, V., Mandpe, A. dan Kumar, S. (2018) "Synergistic effect of fly ash in in-vessel composting of biomass and kitchen waste," Bioresource Technology, 251, hal. 114-120. doi: 10.1016/j.biortech.2017.12.039.

Moelyaningrum, A. D., Ellyke dan Pujiati, R. S. (2013) "Penggunaan dolomit $(\mathrm{MgCa}(\mathrm{CO} 3) 2)$ sebagai penstabil $\mathrm{pH}$ pada komposting 
sampah dapur berbasis dekomposisi anaerob dan aerob," Jurnal IKESMA, 9(2), hal. 74-82.

Murdifi, A. (2017) "Langkah nyata pemanfaatan limbah B3," PLN Fokus, Juni, hal. 6-8.

Noviardi, R. (2013) "Limbah batubara sebagai pembenah tanah dan sumber nutrisi: Studi kasus tanaman bunga matahari (Helianthus annus)," Riset Ceologi dan Pertambangan, 23(1), hal. 61-72.

doi: 10.14203/risetgeotam/2013.v23.70.

Pemerintah Republik Indonesia (2014) Peraturan Pemerintah Nomor 101 Tahun 2014 tentang Pengelolaan Limbah Bahan Berbahaya dan Beracun (B3). Indonesia.

Penn, C. J. dan Bryant, R. B. (2006) "Application of phosphorus sorbing materials to streamside cattle loafing areas," Journal of Soil and Water Conservation, 61(5), hal. 303-310.

Rautaray, S. K., Ghosh, B. C. dan Mittra, B. N. (2003) "Effect of fly ash, organic wastes and chemical fertilizers on yield, nutrient uptake, heavy metal content and residual fertility in a rice-mustard cropping sequence under acid lateritic soils," Bioresource Technology, 90(3), hal. 275-283. doi: 10.1016/S0960-8524(03)00132-9.

Reeves, R. D. dan Baker, A. J. M. (2000) "Metal accumulating plants," in Raskin, I. dan Ensley, B. D. (ed.) Phytoremediation of toxic metals: Using plants to Clean Up the Environment, hal. 193-229.

Rusli, M. S. (2010) Sukses memproduksi minyak atsiri. Jakarta: AgroMedia.

Setiyowati, S., Haryanti, S. dan Hastuti, R. B. (2012) "Pengaruh perbedaan konsentrasi pupuk organik cair tehadap produksi bawang merah (Allium ascalonicum L)," Bioma: Berkala Ilmiah Biologi, 12(2), hal. 44-48. doi: 10.14710/bioma.12.2.44-48.

Singh, A., Sharma, R. K. dan Agrawal, S. B. (2008) "Effects of fly ash incorporation on heavy metal accumulation, growth and yield responses of Beta vulgaris plants," Bioresource Technology, 99(15), hal. 7200-7207.

doi: 10.1016/j.biortech.2007.12.064.

Singh, M. K., Kumar, S. dan Ratha, D. (2016) "Physiochemical and leaching characteristics of fly and bottom ash," Energy Sources, Part A: Recovery, Utilization, and Environmental Effects, 38(16), hal. 2377-2382.

doi: 10.1080/15567036.2015.1057657.
Singh, R. P., Sharma, B., Sarkar, A., Sengupta, C., Singh, P. dan Ibrahim, M. H. (2014) "Biological responses of agricultural soils to fly-ash amendment," in Whitacre, D. M. (ed.) Reviews of Environmental Contamination and Toxicology Volume 232. New York: Springer Cham Heidelberg, hal. 45-60. doi: 10.1007/978-3-319-06746-9_2.

Sinha, S. dan Gupta, A. K. (2005) "Translocation of metals from fly ash amended soil in the plant of Sesbania cannabina L. Ritz: Effect on antioxidants," Chemosphere, 61(8), hal. 1204-1214.

doi: 10.1016/j.chemosphere.2005.02.063.

Stout, W. L., Sharpley, A. N. dan Pionke, H. B. (1998) "Reducing soil phosphorus solubility with coal combustion by-products," Journal of Environmental Quality, 27(1), hal. 111-118. doi:

10.2134/jeq1998.00472425002700010016x.

Thuynsma, R., Kleinert, A., Kossmann, J., Valentine, A. J. dan Hills, P. N. (2016) "The effects of limiting phosphate on photosynthesis and growth of Lotus japonicus," South African Journal of Botany, 104, hal. 244-248. doi: 10.1016/j.sajb.2016.03.001.

Topaç, F. O., Başkaya, H. S. dan Alkan, U. (2008) "Nitrogen mineralization in soils treated with fly ash-Amended wastewater sludges," Communications in Soil Science and Plant Analysis, 39(5-6), hal. 812-823. doi: 10.1080/00103620701880867.

Tosepu, R. (2012) "Laju penurunan logam berat plumbum $(\mathrm{Pb})$ dan cadmium $(\mathrm{Cd})$ oleh Eichornia crassipes dan Cyperus papyrus," Jurnal Manusia dan Lingkungan, 19(1), hal. 37-45.

Truter, W. F. (2008) Sustainable plant production on degraded soil / substrates amended with South African class $F$ fly ash and organic materials. University of Pretoria.

Tuheteru, F. D., Kusmana, C., Mansur, I. dan Iskandar (2015) Potensi Lonkida (Nauclea orientalis L.) untuk fitoremediasi lahan basah air asam tambang. Institut Pertanian Bogor.

Urvashi, Masto, R. E., Selvi, V. A., Ram, L. C. dan Srivastava, N. K. (2007) "An international study: Effect of farm manure on the release of phosphorus from fly ash," Remediation Journal, 17(4), hal. 69-81. doi: 10.1002/rem.20144.

Utami, S. W. (2018) "Karakteristik kimiawi fly ash batu bara dan potensi pemanfaatannya sebagai 
bahan pupuk organik," AGROINTEK, 12(2), hal. 108. doi: 10.21107/agrointek.v12i2.4048.

Verma, C., Madan, S. dan Hussain, A. (2016) "Heavy metal contamination of groundwater due to fly ash disposal of coal-fired thermal power plant, Parichha, Jhansi, India," Cogent Engineering. Diedit oleh S. Dubey, 3(1). doi: 10.1080/23311916.2016.1179243.

Wibowo, H., Riani, E. dan Kurniawan, B. (2018) Strategi kebijakan pengelolaan limbah B3 fly ash dan bottom ash pada pembangkit listrik tenaga uap yang berkelanjutan. Institut Pertanian Bogor.

Wong, J. W. C., Fang, M., Li, G. X. dan Wong, M. H. (1997) "Feasibility of using coal ash residues as CO-Composting materials for sewage sludge," Environmental Technology, 18(5), hal. 563-568.

doi: 10.1080/09593331808616574.

Wong, J. W. C., Li, S. W. Y. dan Wong, M. H. (1995)

"Coal fly ash as a composting material for sewage sludge: effects on microbial activities," Environmental Technology, 16(6), hal. 527537. doi: 10.1080/09593331608616294.

Yunita, N. W. (2018) Tiga tahun jalan, ini progres teranyar proyek $35000 \mathrm{MW}$, www.detik.com. Tersedia pada: https://finance.detik.com/energi/d3932847/tiga-tahun-jalan-ini-progres-teranyarproyek-35000-mw (Diakses: 8 Februari 2020).

Zheljazkov, V. D., Craker, L. E. dan Xing, B. (2006) "Effects of $\mathrm{Cd}, \mathrm{Pb}$, and $\mathrm{Cu}$ on growth and essential oil contents in dill, peppermint, and basil," Environmental and Experimental Botany, 58(1-3), hal. 9-16. doi: 10.1016/j.envexpbot.2005.06.008.

Zhu, X. Q., Wang, C. Y., Chen, H. dan Tang, M. (2014) "Effects of arbuscular mycorrhizal fungi on photosynthesis, carbon content, and calorific value of black locust seedlings," Photosynthetica, 52(2), hal. 247-252. doi: 10.1007/s11099-014-0031-z. 
